\title{
Effect of Leaves Infuse (Foeniculum vulgare Mill.) Intake on Reproductive Organs Morphometry of Female Rats (Rattus Sp.) After Parturition
}

\author{
Najda Rifqiyati*, Jumailatus Sholihah, Laelatul Soimah \\ Biology Department, Faculty of Science and Technology, UIN Sunan Kalijaga Yogyakarta \\ Jl. Marsda Adisucipto No 1 Yogyakarta 55281, Indonesia. Tel. +62-274-540971, Fax. +62-274-519739. \\ *Email: nada_gusna@yahoo.com
}

\begin{abstract}
Rifqiyati N, Sholihah J, Soimah L. 2017. Effect of Leaves Infuse (Foeniculum vulgare Mill.) Intake on Reproductive Organs Morphometry of Female Rats (Rattus Sp.) After Parturition. Proc Internat Conf Sci Engin 1: 27-30. Fennel (Foeniculum vulgare Mill.) traditionally used by people as antifertility agent for female. Fennel leaves (Foeniculum vulgare Mill.) contain phytoestrogen that has role as antiestrogen or synthesized become antiestrogen. Coumarin is the kind phytoestrogen that can be antiestrogen to female reproductive organs such as ovary and utery. The aim of this research is to find out the influence of fennel leaves infuse (Foeniculum vulgare Mill.) on morphometric of ovary and utery in female rats (Rattus sp.) administered after parturition, to find out the effective dose affecting the morphometric of ovary and utery and to find out the total coumarin consisted in fennel leaves (Foeniculum vulgare Mill.). This research was carried out by using CRD (Completely Randomized Design) consisted of 2 groups, those are control group (aquades) and treatment groups (doses of fennel leaves infuse $20 \mathrm{~g} / 300 \mathrm{ml}, 40 \mathrm{~g} / 300 \mathrm{ml}$ and $60 \mathrm{~g} / 300 \mathrm{ml}$ ). The treatment was administered in the morning and afternoon for 15 days. After 15 days of treatment, the rats were sacrificed and dissected to measure the morphometry of reproductive organs (ovary and utery). The data obtained was analyzed by Analysis of Varian (ANOVA) and continued by LSD (Least Significance Different) test with significance of 5\%. The measurement of coumarin level was performed by TLC (Thin Layer Chromatography) densitometry method. The result of this research showed that the administration of infused fennel leaves (Foeniculum vulgare Mill.) at dose of $20 \mathrm{~g} / 300 \mathrm{ml}, 40 \mathrm{~g} / 300 \mathrm{ml}$ and $60 \mathrm{~g} / 300 \mathrm{ml}$ significantly decreased ovarian weigh in female rats (Rattus sp.) after parturition $(p<0,05)$, but not decreased the length, width, thick of ovary, length and diameter of utery $(p>0,05)$. No difference was observed between doses $20 \mathrm{~g} / 300 \mathrm{ml}, 40 \mathrm{~g} / 300 \mathrm{ml}$ and $60 \mathrm{~g} / 300 \mathrm{ml}$, and it showed that the dose $20 \mathrm{~g} / 300 \mathrm{ml}$ of fennel leaves infuse was able to be used to decrease the weigth of ovary. Coumarin level observed in leaves is $0,09 \%$, and it is higher than the coumarin content in fruit/seed.
\end{abstract}

Keywords: Coumarin, Fennel leaves (Foeniculum vulgare Mill.), Morphometric of reproductive organs, Rattus sp.

\section{INTRODUCTION}

Fennel (Foeniculum vulgare Mill.) is native to Southern Europe and Asia and widely planted in Indonesia, India, Argentina,Europe and Japan. The plants are extensively cultivated for their fruit. In Indonesia, the fennel is used for seasoning or medicinal plant purposes. The fennels are usually found in tropical regions, grow from lowlands to $1800 \mathrm{~m}$ of altitude, however, they will grow better at highlands (Dalimartha, 2000).

Traditionally, fennel plants are used as source of infertility agent for women. The fennels are used in traditional Chinese medicine for treatment of rheumatism, pain, and as aromatic materials for treatment of stomach disorders. The fennel useful materials contain some phenolic compounds, transanethole, estragole, and fenchone (Akbar, 2010). Fennel leaves are the main photosynthetic organs that have hairy structures, high water content, high content of volatile oils, phenol, potassium compounds, and chlorophyll. The contents of fennel leaf are beneficial to health and has useful compounds that can cure a disease (Shanti et al., 2014).

The use of natural materials containing hormone or phytohormone, one of which is phytoestrogen, have been developed currently. Phytoestrogen is a substratum of plant that having similar activity as estrogen. The phytoestrogen, a natural compound which is found in plants, has a lot of common characteristics with estradiol, one of the most potential estrogen. The use of phytoestrogen is predicted safer than synthetic estrogen or the other hormonal substitution drugs (Jhonson, et al., 2003).

Fennels contain phytoestrogen that can be estrogenic or antiestrogenic. One of phytoestrogen compound contained in fennel leaves is belong to flavonoid group (Rifqiyati, 2016). The phytoestrogen compound that can act as antiestrogen or can be synthesized to be antiestrogen is coumarin. Coumarin is one of secondary metabolite with ana-benzophyrone-based structure having physiological and pharmacological effects, such as in influencing synthesis of estrogen. Therefore, it affects the development of ovum in the ovary and blocking of cells in endometrial lining of uteri (Rusmiati, 2011 in Hidayati, 2015).

Some researches on fennel effects have been conducted, one of them is a research using fennel seed infusion showed that it affected sleep duration in mice (Pudjiastutiet al., 1998). Another study conducted by Khazei et al. (2011) demonstrated that the fennel seeds also influenced folliculogenesis in female rats. It is also suggested in another study by Rabia (2015) that some parts of the fennel plants (stem, leaves and seeds) can be 
used in cancer treatment. However, the research on the plant effects related to morphometric study of female reproductive organs of rats, and the study on the fennel leaves, are still rarely conducted. Sa'roni et al (1999) showed that fennel seeds affect female reproductive organs and can be used as an alternative to oral contraceptive. Therefore, this study aimed to observe the effect of fennel leaf infusion on morphometric characteristics of ovary and uteri in female rats postpartum.

\section{MATERIALS AND METHODS}

\section{Plant Material and Infusion Preparation}

Foeniculum vulgare Mill. plants were collected from Kopeng, Semarang, Central Java. The infusion was prepared by cutting fennel leaves into small pieces (4-5 centimeters) and put in oven with the temperature $40^{\circ} \mathrm{C}$ for a few days until reaching a constant weight. The dry leaves then were grinded and sifted until finely powdered. The powder then was weighed about 20 grams to make the $20 \mathrm{~g} / 300 \mathrm{ml}$ infusion, 40 grams for $40 \mathrm{~g} / 300 \mathrm{ml}$ infusion and 60 grams for $60 \mathrm{~g} / 300 \mathrm{ml}$ infusion. The powder was put in beaker glasses and then soaked in $300 \mathrm{ml}$ water. The mixture was heated to $90^{\circ} \mathrm{C}$ on a hotplate for 15 minutes, then filtered twice to achieve $100 \mathrm{ml}$ infusion (Pidada, 2004).

\section{Animal treatments}

A total of 12 pregnant, female rats were acclimated for one week and fed ad libitum. After parturition, all adultand-offspring rats are divided into four groups, and every group consisted of three repetitions (put in separated enclosures). Every enclosure consisted of a mother rat and five offspring. The mother rats were then treated by administering the fennel leaf infusion orally using syringe. The doses weredelivered twice a day, $1 \mathrm{ml}$ infusion (or aquadest in control groups) delivered in every morning and afternoon for 15 days, from the $3^{\text {rd }}$ to the $7^{\text {th }}$ day of lactation period. The doses for every groups are arranged as following:
a. Control
: aquadest
b. Treatment I (T1) : fennel leaf infusion $(20 \mathrm{~g} / 300 \mathrm{ml})$
c. Treatment II (T2) : fennel leaf infusion $(40 \mathrm{~g} / 300 \mathrm{ml})$
d. Treatment III (T3) : fennel leaf infusion $(60 \mathrm{~g} / 300 \mathrm{ml})$

The rat mother were sacrificed and dissected on the $17^{\text {th }}$ day of lactation period. The morphometric measurement was carried out on fresh reproductive organs including ovaries and uteri by measuring the weight, length, width, and the thickness of the organs (Jalaludin, 2014). The length of uteri was measured from beginning part of cornua (cranial cornua) to the end of cornua (caudal cornua). The diameter of uteri was measured on parts of cornua that are adjacent to fallopi, to middle cornua and to the end of cornua (adjacent to cervix) (Jamalia, 2006).

\section{Coumarin analysis}

Determination of steroid levels in the fennel leaves were conducted by TLC (Thin Layer Chromatography)densitometry method. The process was started by weighing the powdered leaf sample and adding $2 \mathrm{ml}$ ethanol into flasks, then mixing them by vortex and then separating the extract phases by centrifugation. The ethanol phase was then collected and the extraction was repeated twice. The ethanol phase was then evaporated and resuspended with $1 \mathrm{ml}$ ethanol, then spotted on silica gel $60 \mathrm{~F}_{254}$ plate, including a coumarin standard. The samples then were put into chamber containing saturated of motion phases of toluene-ether (1-1, until saturated with $10 \%$ acetic acid). After being evaluated to the end of solid phase, the plate then was removed and dried. The level of coumarin was determined using densitometer at 304nm (Anonymous, 2016).

\section{Statistical analysis}

Data analysis were performed using a one-way analysis of variance (ANOVA) and continued by LSD (Least Significance Difference) test with significance using $95 \%$ confidence.

\section{RESULTS AND DISCUSSION}

\section{Results}

The effect of administration of fennel (Foeniculum vulgare Mill.) leaf infusion to morphometric characteristics of ovary, by measuring the length, width, thickness, and weight of ovary is presented in Table1.

Table 1. The average of length, width, thickness, and weight of ovary measured for every variation of doses.

\begin{tabular}{cccccc}
\hline Numb. & Treatments & Length $(\mathbf{c m} \pm$ SD $)$ & Width $(\mathbf{c m} \pm$ SD $)$ & Thickness $(\mathbf{c m} \pm$ SD) & Weight $(\mathbf{g} \pm$ SD $)$ \\
\hline 1 & Control & $0.76 \pm 0.11^{\mathrm{a}}$ & $0.70 \pm 0.03^{\mathrm{b}}$ & $0.40 \pm 0.02^{\mathrm{cb}}$ & $0.05 \pm 0.00^{\mathrm{a}}$ \\
2 & $\mathrm{~T} 1$ & $0.69 \pm 0.09^{\mathrm{a}}$ & $0.66 \pm 0.06^{\mathrm{b}}$ & $0.36 \pm 0.02^{\mathrm{cb}}$ & $0.04 \pm 0.00^{\mathrm{b}}$ \\
3 & $\mathrm{~T} 2$ & $0.59 \pm 0.10^{\mathrm{a}}$ & $0.63 \pm 0.14^{\mathrm{b}}$ & $0.42 \pm 0.04^{\mathrm{cb}}$ & $0.04 \pm 0.00^{\mathrm{b}}$ \\
4 & $\mathrm{~T} 3$ & $0.58 \pm 0.04^{\mathrm{a}}$ & $0.62 \pm 0.11^{\mathrm{b}}$ & $0.42 \pm 0.01^{\mathrm{cb}}$ & $0.04 \pm 0.00^{\mathrm{b}}$ \\
\hline
\end{tabular}

Note: The different character of superscripts in the same column showed significant differences $(\mathrm{p}<0.05)$. 
In general, table 1 shows that the higher doses of fennel leaf infusion caused less averages of ovary length, width, and thickness, but no differences in its weight. Based on statistical analysis, there were no significant differences observed between control and experimental groups $(\mathrm{T} 1, \mathrm{~T} 2, \mathrm{~T} 3)$ in ovary length, width and thickness ( $>0.05)$, and there was significant differenceobserved between control groups and all experimental groups $(\mathrm{T} 1, \mathrm{~T} 2, \mathrm{~T} 3)$ in weight of ovary $(\mathrm{p}<0.05)$.

The effect of administration of fennel (Foeniculum vulgare Mill.) leaf infusion on morphometric characters of uteri by measurement of length and diameter of uteri is presented in Table2.

Table2. The averageof length and diameter of uterimeasured for every variation of doses.

\begin{tabular}{cccc}
\hline Numb. & Treatments & Length $(\mathbf{c m} \pm$ SD $)$ & Diameter $(\mathbf{c m} \pm$ SD $)$ \\
\hline 1 & Control & $2.16 \pm 0.26^{\mathrm{a}}$ & $0.36 \pm 0.06^{\mathrm{b}}$ \\
2 & T1 & $3.12 \pm 0.96^{\mathrm{a}}$ & $0.33 \pm 0.01^{\mathrm{b}}$ \\
3 & T2 & $3.10 \pm 0.56^{\mathrm{a}}$ & $0.35 \pm 0.09^{\mathrm{b}}$ \\
4 & T3 & $3.20 \pm 0.32^{\mathrm{a}}$ & $0.29 \pm 0.07^{\mathrm{b}}$ \\
\hline
\end{tabular}

Note: The same character of superscripts in the same column showed no significant differences among treatments ( $\mathrm{p}>0.05)$.

The Table 2 above shows that the fennel leaf infusion delivered to female rats during lactation period can decrease diameter of uterus. However, the statistical analysis suggested that there are no significant differences between control and experimental groups $(\mathrm{T} 1, \mathrm{~T} 2, \mathrm{~T} 3)$ either in the length or diameter of uteri (p>0.05),although we can notice that there are slight decreases in diameter of uterifollowing the increment of doses in experimental groups $(\mathrm{T} 1, \mathrm{~T} 2, \mathrm{~T} 3)$.

\section{Discussion}

The insignificant differences in morphometric characters, either observed in ovary or uteri, are estimated due to very low levels of phytoestrogen given on treatment groups (T1, T2, T3). It was earlier known that the binding affinity of phytoestrogento estrogen receptors, such as Er $\alpha$ and $\mathrm{ER}_{\beta}$, isweaker than the $17_{\beta}$ estradiol (Tsourounis, 2004). Furthermore, it is also predicted that in order to get more significant results, it will need more time in treatment than those conducted in this study. Reduced size of ovary, observed after treatment with higher doses, was predicted due to higher level of phytoestrogen,that having anti-estrogenic nature, compared to $17_{\beta}$ estradiol level.

The significant difference in weight of ovary is predicted because of the effect of the phytoestrogen content in the fennel leaf infusion. Some mechanisms of phytoestrogens (coumarins) in affectingthe development of ovary is by destructing cells and forming pores incell membrane, therefore they can change the structure and function of plasma membrane. Consequently, they can affect transmembrane activity, causing leakage of amino acid or other contents of cytoplasm, so that the cells may shrinks and destroyed (Widodo et al., 2012).

There is no significant difference between experimental groups (T1, T2, T3) in ovarian weight based on the LSD test. This result is predicteddue to lack of estrogenic receptors available to bind the phytoestrogen. The availability of estrogenic receptors affects phytoestrogen in resulting particular effect on reproductive organs. The phytoestrogen will block cell proliferation by binding to estrogenic receptors. So, when the number of receptor are already saturated (by another hormone with higher affinity to receptor), then the increasing level of phytoestrogen cannotresult in more significant expressionsdriven by estrogenic receptors (Susanto et al., 2014).

The change of morphometric characters in uteri is strongly influenced by hormonal activity. A study carried out by Sa'roni (1999) showed that infusion of fennel fruit with doses $219 \mathrm{mg} / 100 \mathrm{~g}$ of body weight could decrease the weight of uteri.The thickness of endometrium is considered as a main factor affectingthe weight of uteri. Furthermore, it is needed to histologically observe the uteri to know the structure of endometrial lining, which affect the morphometry of uteri.

The rising level of estrogen hormone will give a negative feedback on hypothalamus that affecting ovary, and this will lead to declining in secretion of FSH and LH.The Follicle Stimulating Hormone (FSH) and Lutheinizing Hormone (LH) are responsible in synthesis of estrogenic hormone and progesterone in the ovary. A disruption in estrogenic hormone synthesis in the ovary may inhibit the uteri-wall-forming cells to proliferate. Therefore, the uteri wall thickening and blood vessels growthwill also be interrupted (Junqueira\& Jose, 1995 in Rusmiati, 2011).

The analysis of coumarin contentusing TLCdensitometry obtained the average level of coumarin in fennel leaves is $0.09 \%$. This is higher than coumarin level in fennel fruits/seeds (0.03\%) (Fuping et al., 2014). The fennel fruit infusion was known have an antiestrogenic effect to reproductive organs and can be developed to be an alternative for oral contraceptives. 


\section{CONCLUSIONS}

The present study suggested the fact that fennel (Foeniculum vulgare Mill.) leaf infusion has an antiestrogenic effect to decrease the weight of ovarian in postpartum female rats. Further studies are recommended to observe the histology of ovary and uteri for advanced study on the process of folliculogenesis, and factors related to the width of uteri.

\section{ACKNOWLEDGEMENTS}

The authors wish to express gratitude to LP2M of Sunan Kalijaga University for support this research.

\section{REFERENCES}

Akbar, Budhi. (2010).Herb with active compound potentially as an antifertility agen.Jakarta: Adabia Press, State Islamic Universityof SyarifHidayatullah Jakarta.

Anonim. (2016). Worksheet of chemical test of research lab and intergrated. Yogyakarta: LPPT UGM.

Dalimartha. (2000). The atlas of herb drug in Indonesia (2).Jakarta: Trubus.

Fuping, X. J. S. B. Z., \& Yi, L. Y. C. (2004). Study on Volatiles in FoeniculumVulgareMill by Gas Chromatrography-mass Spectrometry Combiningwith Simultaneous Distillation and Solvent Extraction. Journal Food and Fermentation Industries, 12: 29.

Hidayati, N.D.L., Rizki, K. danGanjar T.P. (2015). Potential extract of ethanol of custard apple leaves (Annona squamosa L.) as antifertility agen in mice of wistar strains. Journal of MedicineBakti Tunas Husada, 13(01): 82-88.

Ibrahim, F.Y., El-Khateeb, A.Y. (2013). Efect Herbal Beverages of Foeniculum vulgare and Cymbopogonproximus on inhabitation of calcium oxalate renal cryltals formation in rats. Annals of agricultural Science, 58(3): 221-229.

Jalaluddin, M (2014). Morphometric and characteristic histological characteristic of Bos indicusin estrus cycle. Jorrnalof Veterinary Medicine, 8(01): 66-68.

Jamalia, Rifka. (2006). The study of anatomy characteristic and morphometric reproductive organs of local female horses in Indonesia.Bogor: The faculty of Veterinary Medicine IPB.
Johnson. I. \& Gary. W. (2003). Phytochem functional foods. USA: CRC Press Inc.

Johnson, M.H. \&Everrit, B. J. (1988).Essential Reproduction (3 ${ }^{\text {rd }}$ Edition). London: Blackwell Sci Publishing.

Junqueira, L.C., J, Carnairo, Keley, R.O. (1992).Fundamental of histology . Jakarta: EGC.

Kariyil, Bibu John. (2010). Phytoestrogen in Animal Origin Foods. Veterinary World, 3 (1): 43-45.

Pidada, IB. Rai. (2004). The comparison an increase weight in female mice induced by papaya infuce and Sauropusandogynus. Berk. Penel. Hayati, 10: (49-52).

Raven, P., \& Johnson, G. (2002). Biology 6th ed. NY: McGrawHill Publishing.

Rifqiyati, Najda. (2016). The contents of nutrition and phytochemical compound of fennel leaves (Foeniculum vulgare Mill). Prosidingsemnarbiodiversitas, 5(01): 92-95.

Robinson, Trevor. (1995). The organic contents of higher plants. (Ed Ke-6) Translation of: K. padmawinata. Bandung: Institute of Technology Bandung.

Rusmiati, 2011. Experiment of antifertility effect of N-Heksan and acetil acid of the leather stems of (DuriozibethinusMurr) in histological structure of mice (Mus musculus L.). Journal of Science danApplied Science, 5 (01):1-7.

Sa'roni\&Imono, A. Donatus. (1999). The influence of fruits infuce of Foeniculum vulgare Mill on Estrus Cyle and the weight of female rats. Litbang Media Special Edition 'Original Drug of Indonesia, 8 (3\&4): 2-5

Setiawan. (2010). The activity of methanol extract in fruits (Foeniculum vulgare Mill) to the duration of estrus cycle and weight of uteri and ovary. Bogor: The Faculty of Veterinary Medicine, InstitutPertanian Bogor.

Shanthi. Rini Verary, Jumari\&Munifatul. Izzati. (2014). The study of etnobotanical of traditional medicine for treatment of women in Surakarta Hadiningrat. Biosaintifika, 6(2):65-67.

Susanto, Donny, Sri, Pantja. Madyawati. \& Imam, Mustofa. (2014). The administrate of Epigallocathechin gallate $(E G C G)$ to the ekspression of estrogene receptors in female rats (Rattusnorvegicus). VeterinariaMedika, 7(1):57-62

Tsourounis, C. (2004). Clinical effects of fitoestrogens. Clinical Obstetrict and Genycology, 44(4):836-42.

Widodo, G.P., Elin, Y.S., I ketut, A. \& Sukrasno. (2012). Mechanism of Action of Coumarin against Candida albicans by SEM/TEM Analysis. ITB J. Sci, 44(02): 145-151. 